\title{
Metabolism of heat-damaged proteins in the rat
}

\section{Inhibition of amino acid uptake by ' unavailable peptides' isolated from enzymic digests of heat-damaged cod fillet}

\author{
BY C. SHORROCK* AND J. E. FORD \\ National Institute for Research in Dairying, Shinfield, Reading RG2 $9 A T$
}

\section{(Received 29 April 1977 - Accepted 8 January 1978)}

\begin{abstract}
I. An extract containing 'unavailable' small peptides was isolated from an enzymic digest of heatdamaged cod fillet and examined for its influence on uptake of leucine in the rat small intestine, using the everted-sac technique.

2. The extract strongly inhibited the uptake of leucine. It had no effect on uptake of glucose or its metabolism to lactate.

3. The findings are discussed in relation to the concept (Buraczewski, Buraczewska \& Ford, 1967) that the accumulation of 'unavailable peptide' material in the intestine, found in rats given heat-damaged protein, might hinder the absorption of amino acids by blocking a mechanism involved in their transport across the mucosal barrier.
\end{abstract}

In studies of the influence of heating cod fillet on the course of its digestion in the rat, Buraczewski et al. (1967) found that there were very much higher concentrations of free amino acids and small peptides in the intestinal contents of animals that had been given severely-heated protein than in control animals given undamaged protein and yet, conversely, the concentrations of free amino acids in the portal blood were much lower. To explain this anomaly they postulated that the accumulation of 'unavailable peptide' material in the intestine, characteristic for heat-damaged proteins, might hinder the absorption of amino acids by saturating the sites involved in their transport across the mucosal barrier.

The present paper reports experiments on the influence of 'unavailable peptides' isolated from enzymic digests of heat-damaged cod fillet on the uptake of leucine from everted sacs of rat small intestine.

\section{MATERIALS AND METHODS}

Cod fillet. A $3 \mathrm{~kg}$ block of frozen cod fillets was freeze-dried and milled to form a light flocculent powder. A portion of this preparation was then heated for $20 \mathrm{~h}$ in an air oven at $135^{\circ}$, as described by Ford \& Shorrock (197I).

Preparation of enzymic digests. The test proteins were digested successively with pepsin, pancreatin and erepsin, as described by Ford \& Salter (1966). The enzymic digests were clarified by centrifugation, and diluted with water to contain $5 \mathrm{mg}$ nitrogen $/ \mathrm{ml}$.

Gel filtration. The enzymic digest was resolved into extracts containing 'undigested protein', 'peptides' and 'free amino acids' by filtration in a calibrated column of Sephadex gel G 25 (Pharmacia (GB) Ltd, London), essentially as described by Ford (I965). The settled height of the gel column was $600 \mathrm{~mm}$ and its diameter $42 \mathrm{~mm}$. Portions (IO ml) of the digests were applied to the column which was then eluted with buffer solution, $\mathrm{pH} 7 \cdot 6$, containing $0.02 \mathrm{M}$-sodium phosphate and $0 . \mathrm{I} \mathrm{M}$-sodium chloride, and eighty $10 \mathrm{ml}$ fractions were collected. Fraction nos. 32-4I from the digest of the heat-damaged protein were combined to obtain the 'unavailable peptides' preparation and this was freeze-dried.

* Present address: Animal Production Research Unit, Private Bag 0033 , Gaborone, Botswana. 
Microbiological assay procedures. (a) Assay of total and available methionine, leucine, isoleucine, and valine in enzymic digests with Streptococcus zymogenes was performed by the procedure of Ford (1962, 1964) modified as described by Boyne, Ford, Hewitt \& Shrimpton (1975); (b) assay of available lysine with Tetrahymena pyriformis was done using the procedure of Shorrock (1976); (c) assay of total lysine with Pediococcus cerevisiae P6o was done using the procedure of Barton-Wright (1963) modified as described by Shorrock (1976).

Preparation of everted sacs of rat small intestine. Everted intestinal sacs were prepared by the method described by Wilson \& Wiseman (1954). Male hooded Norwegian rats weighing approximately $200 \mathrm{~g}$ were maintained on a commercial pelleted diet (Spillers Small Animal Diet; Spratts Patents Ltd, Central House, Cambridge Road, Barking, Essex). The animals were killed by a blow on the head and a $200 \mathrm{~mm}$ length of the upper ileum was taken from the small intestine, the mesentery was removed and the intestine was washed out three times with Krebs-Ringer bicarbonate buffer (Krebs \& Hensleit, 1932) and everted over a glass rod of $2 \mathrm{~mm}$ diameter. Each of these lengths of intestine was made into three sacs each $20-30 \mathrm{~mm}$ in length, as follows. One end of each length was tied with cotton thread, and a blunt-ended hypodermic needle tied into the other end. Through this needle $0.7 \mathrm{ml}$ of the serosal solution was injected into the sac, which was tied off as the needle was withdrawn. Six sacs, three from each of two rats, were prepared on each test occasion. Each was placed in $10 \mathrm{ml}$ of the mucosal solution in a sintered-glass funnel as described by Ford (1971). Oxygen-carbon dioxide $(95: 5, \mathrm{v} / \mathrm{v})$ was bubbled slowly through the disc of the funnel, serving the dual purpose of mixing and oxygenating the mucosal solution. Each funnel was clipped into a water-bath maintained at $37^{\circ}$. The sacs were incubated for $30 \mathrm{~min}$ and then removed from the funnel. The mucosal and serosal fluids were collected and their volumes measured.

In experiments to determine uptake of leucine alone, the sacs were incubated in KrebsRinger solution containing: mucosal fluid: I mM-leucine, including $0.25 \mu \mathrm{Ci}$ [U-1 ${ }^{14} \mathrm{C}$ ]leucine, 0. I I M-glucose; serosal fiuid: I mM-leucine, 0. I I M-glucose. In experiments on the influence of 'unavailable peptides' on uptake of leucine the Krebs-Ringer solution contained: mucosal fluid: I mM-leucine including $0.25 \mu \mathrm{Ci}\left[\mathrm{U}-{ }^{14} \mathrm{C}\right]$ leucine, $0.01 \mathrm{I} \mathrm{M-glucose,} 50 \mu \mathrm{g}$ total leucine as 'unavailable peptide'/ml; serosal fluid: I mM-leucine, 0.0 I I M-glucose.

Absorption of leucine from the mucosal fluid, and transfer to the serosal fluid, was determined microbiologically with Strep. zymogenes. In addition ${ }^{14} \mathrm{C}$-labelled leucine was determined in the mucosal fluid after incubation. A sample of the fluid ( $0.1 \mathrm{ml}$ ) was taken into a glass scintillation vial and $10 \mathrm{ml}$ of scintillator solution containing, per 1 toluene, $4 \mathrm{~g} \mathrm{2,5-diphenyloxazole} \mathrm{and} 0.3 \mathrm{~g}$ I,4-bis-(5-phenyloxazole-2-yl)benzene added. Counting was carried out using a liquid-scintillation spectrometer (Tri-Carb Model 3315; Packard Instrument $\mathrm{Co}$, Ilinois, USA). Correction for quenching of the sample was made by addition of an internal standard of ${ }^{14} \mathrm{C}$-labelled toluene.

Determination of glucose. Glucose in the mucosal fluids was determined by the method of Dahlquist (1964).

Determination of lactate. Lactate in serosal fluids was determined using the Lactate Test Combination Kit (Boehringer Corporation, London). Serosal fluid was diluted fourfold with $0.6 \mathrm{M}$-perchloric acid. A sample $(0.1 \mathrm{ml})$ was then mixed with $0.03 \mathrm{ml}$ of a solution containing $60 \mu \mathrm{g}$ lactate dehydrogenase (EC I.I.I.27) and $2.0 \mathrm{ml} 0.5 \mathrm{M}$-glycine buffer, $\mathrm{pH} 9.0$, containing $0.027 \mathrm{M}-\mathrm{NAD}$. The mixture was incubated for $\mathrm{I} h$ at $25^{\circ}$, and the extinction at $366 \mathrm{~nm}$ was measured. A standard L-lactate solution containing $9 \mu \mathrm{g} \mathrm{L}$-lactate/ $0.1 \mathrm{ml}$ was carried through the same procedure. 
Table I. Total and available amino acid content $(\mathrm{g} / \mathrm{kg}$ crude protein (nitrogen $\times 6 \cdot 25)$ ) of enzymic digests of cod fillet preparations. Total and available lysine were determined microbiologically with Pediococcus cerevisiae $\mathrm{P} 60$ and Tetrahymena pyriformis respectively; all other values were determined microbiologically with Streptococcus zymogenes*

(Mean values for two determinations; values in parentheses are available amino acid values expressed as a proportion of the total amino acid value)

\begin{tabular}{|c|c|c|}
\hline Amino acid & $\begin{array}{l}\text { Freeze-dried } \\
\text { cod fillet }\end{array}$ & $\begin{array}{l}\text { Cod fillet heated } \\
\text { at } 135^{\circ} \text { for } 20 \mathrm{~h}\end{array}$ \\
\hline $\begin{array}{l}\text { Methionine } \\
\text { Total } \\
\text { Available }\end{array}$ & $\begin{array}{l}33 \\
3 \mathrm{I}(0.94)\end{array}$ & $\begin{array}{l}27 \\
14(0.52)\end{array}$ \\
\hline $\begin{array}{l}\text { Leucine } \\
\text { Total } \\
\text { Available }\end{array}$ & $\begin{array}{l}84 \\
79(0.94)\end{array}$ & $\begin{array}{l}84 \\
48(0.57)\end{array}$ \\
\hline $\begin{array}{l}\text { Isoleucine } \\
\text { Total } \\
\text { Available }\end{array}$ & $\begin{array}{l}52 \\
51(0.98)\end{array}$ & $\begin{array}{l}51 \\
32(0.63)\end{array}$ \\
\hline $\begin{array}{l}\text { Histidine } \\
\text { Total } \\
\text { Available }\end{array}$ & $\begin{array}{l}20 \\
18(0.90)\end{array}$ & $\begin{array}{l}16 \\
8(0.50)\end{array}$ \\
\hline $\begin{array}{l}\text { Valine } \\
\text { Total } \\
\text { Available }\end{array}$ & $\begin{array}{l}56 \\
56(1 \cdot 00)\end{array}$ & $\begin{array}{l}56 \\
32(0.57)\end{array}$ \\
\hline $\begin{array}{l}\text { Lysine } \\
\text { Total } \\
\text { Available }\end{array}$ & $\begin{array}{l}89 \\
85(0.96)\end{array}$ & $\begin{array}{l}64 \\
18(0 \cdot 28)\end{array}$ \\
\hline
\end{tabular}

* For details of experimental procedures, see pp. $185,186$.

\section{RESULTS}

\section{Content of some amino acids in the digested-cod-fillet preparations}

The total and available amino acid content of the test digests is shown in Table I. The digest of the heat-damaged cod fillet contained reduced amounts $(\%)$ of the following amino acids compared with the unheated cod meal: 28 lysine, 20 histidine, 18 methionine. In the digest of the freeze-dried cod fillet the amino acids were all highly available as judged in the microbiological tests, whereas in the digest of the heat-damaged cod fillet the value for available: total amino acid ranged from 0.63 for isoleucine to 0.28 for lysine.

\section{Sephadex gel filtration}

Fig. I shows the distribution of $\alpha$-amino- $N$ in the fractions obtained by Sephadex gel filtration of the two digests. The digest of the unheated cod meal contained predominantly small peptides and free amino acids, whereas the heated cod meal yielded relatively much more material of larger molecular weight. Thus although $80 \%$ of the heated cod meal was dissolved by the enzyme treatment, it was still far from completely digested. Heating had retarded the course of digestion of the cod fillet, as was also shown by Ford (1965) using a similar heated-cod-fillet preparation. These in vitro findings are closely paralleled by the in vivo results reported by Buraczewski et al. (1967) who found that in the intestinal contents of rats given heated cod fillet there was much more undigested protein and peptide material than in control rats given unheated cod fillet. 


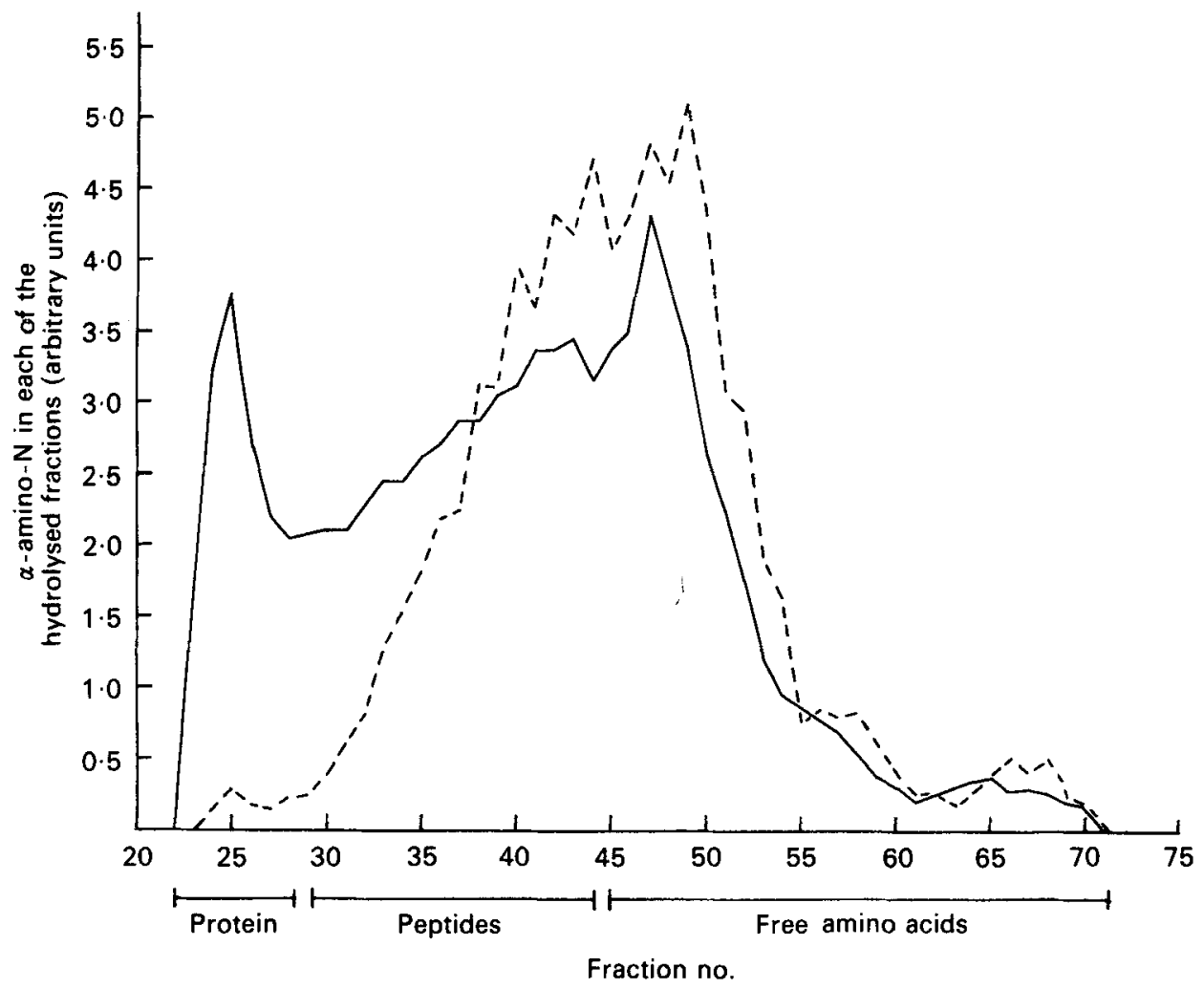

Fig. 1. Fractionation in Sephadex gel G-25 of enzymic digests of freeze-dried (---) and heated $(-)$ cod fillet. $\alpha$-Amino-nitrogen was measured by reaction with ninhydrin, after hydrolysis of each fraction with $6 \mathrm{~m}$-hydrochloric acid. For details of procedures, see p. 187 .

Experiments with everted intestinal sacs

Absorption of leucine from everted intestinal sacs was expressed in terms of the value for final serosal concentration: final mucosal concentration of leucine. This value is an indication of the ability of the gut wall to concentrate leucine against a concentration gradient. The results of the experiments to measure the uptake of leucine alone and in the presence of unavailable peptides and the uptake of glucose and its metabolism to lactate are shown in Table 2. The content of some amino acids in the 'unavailable peptides' fraction is shown in Table 3.

In the absence of 'unavailable peptides' the value for serosal: mucosal uptake for leucine was $2.00 \pm 0.13$ (mean $\pm \mathrm{SD}$ ). The initial concentration of glucose in the mucosal and serosal fluids was $2000 \mu \mathrm{g} / \mathrm{ml}$. After incubation for $30 \mathrm{~min} 348 \pm 42 \mu \mathrm{g} / \mathrm{ml}$ had disappeared from the mucosal fluid, representing a loss of approximately $18 \%$ of the glucose, which was accompanied by an increase in the lactate found in the serosal fluid of $269 \pm 28 \mu \mathrm{g} / \mathrm{ml}$.

In experiments on the influence of the 'unavailable peptides' preparation, it was added to the mucosal fluid only, in amounts contributing approximately $50 \mu \mathrm{g}$ total leucine $/ \mathrm{ml}$ of which approximately $6 \mu \mathrm{g} / \mathrm{ml}$ was available as measured microbiologically with Strep. zymogenes. This concentration of peptides, added to the I mM-leucine already present, increased the total leucine content of the mucosal fluid to approximately $180 \mu \mathrm{g} / \mathrm{ml}$ and the available leucine content to $136 \mu \mathrm{g} / \mathrm{ml}$. From Table 2 it is clear that the presence of this 'unavailable peptide' had a marked effect on the uptake of leucine. The value (mean $\pm S D$ ) for serosal:mucosal uptake of I mm-leucine decreased from $2 \cdot 00 \pm 0.13$ to $1 \cdot 30 \pm 0.12$ in the presence of 'unavailable peptide' and this difference was highly significant. The loss of 
Table 2. Uptake of leucine and glucose and production of lactate alone in everted sacs of rat small intestine and in the presence of 'unavailable peptides' isolated from enzymic digests of heat-damaged cod fillet $\uparrow$; uptake of leucine was measured both by determination of radioactive counts and microbiologically with Streptococcus zymogenesł

(Values in parentheses are mean values and standard deviations; nos. of determinations)

\begin{tabular}{|c|c|c|c|c|c|c|}
\hline \multirow{4}{*}{$\begin{array}{l}\text { Uptake of leucine }(\mu \mathrm{g} / \mathrm{ml}): \\
\text { Determined microbiologically } \\
\text { Determined by radioactive counts }\end{array}$} & \multicolumn{3}{|c|}{ Peptides absent } & \multicolumn{3}{|c|}{ Peptides present } \\
\hline & Mean & & & Mean & $\mathbf{s}$ & D \\
\hline & $21 \cdot 7$ & I. O & $(\mathrm{I} 6)^{*}$ & $8 \cdot 0$ & 0.5 & $(16)^{*}$ \\
\hline & $24 \cdot 3$ & $2 \cdot 1$ & (16) & $12 \cdot 7$ & 3.I & (I6) \\
\hline $\begin{array}{l}\text { Loss of glucose from mucosal } \\
\text { fluid }(\mu \mathrm{g} / \mathrm{ml})\end{array}$ & 348 & 42 & (I 2) & 354 & 45 & (12) \\
\hline $\begin{array}{l}\text { Lactate concentration in serosal } \\
\text { fluid }(\mu \mathrm{g} / \mathrm{ml})\end{array}$ & 269 & 28 & (I2) & $25 \mathrm{I}$ & 24 & (I2) \\
\hline Serosal:mucosal leucine & $2 \cdot 00$ & 0.1 & (I6) & $1 \cdot 30$ & $0 \cdot 12$ & $2(16)$ \\
\hline
\end{tabular}

$* P<0.00 \mathrm{I}$.

$\dagger$ For details of samples, see pp. $185,186$.

$\ddagger$ For details of experimental procedures, see p. 186 .

Table 3. Total and available amino acids $(\mu \mathrm{g} / \mathrm{ml})$ in the 'unavailable peptides' fraction as determined microbiologically

$\begin{array}{lcc} & \text { Total } & \text { Available } \\ \text { Lysine } & 322 & 24 \\ \text { Methionine } & 69 & 21 \\ \text { Leucine } & 233 & 61 \\ \text { Isoleucine } & 192 & 48 \\ \text { Valine } & 160 & 47\end{array}$

* For details of experimental procedures, see p. 186.

leucine from the mucosal fluid as measured microbiologically and by radioactive counts were in good agreement indicating that there was no dilution of the radioactive leucine with leucine released from the 'unavailable peptides' preparation.

The amount (mean $\pm \mathrm{SD}$ ) of leucine lost from the mucosal fluid in the absence of ' $u n$ available peptides' was $2 \mathrm{I} \cdot 7 \pm \mathrm{r} \cdot 0 \mu \mathrm{g} / \mathrm{ml}$ determined microbiologically and $24 \cdot 3 \pm 2 \cdot \mathrm{I} \mu \mathrm{g} / \mathrm{ml}$ determined by radioactive counts. In the presence of ' unavailable peptides' the corresponding values were $8 \cdot 0 \pm 0.5 \mu \mathrm{g} / \mathrm{ml}$ and $\mathrm{I} 2 \cdot 7 \pm 3 . \mathrm{I} \mu \mathrm{g} / \mathrm{ml}$. The presence of the 'unavailable peptides' had no effect on the uptake of glucose or its metabolism to lactate.

\section{DISCUSSION}

The results obtained clearly show that there was inhibition of uptake of leucine from everted intestinal sacs in the presence of the eluate fraction from a Sephadex column that contained the 'unavailable peptides' from an enzymic digest of heat-damaged cod fillet. We are making the assumption for the purpose of our further discussion that it was indeed the peptides in this fraction that were responsible for the effects observed.

The findings for uptake of leucine alone are in fair agreement with those of other workers. Serosal: mucosal uptake of I mM-leucine was $2 \cdot 00 \pm 0 \cdot 13$. This value is approximately twice that found by Wilson \& Wiseman (I954) who reported a value of $I \cdot 18$ for serosal: mucosal leucine absorbed at an initial concentration of $20 \mathrm{mM}$. The difference was probably due to 
the different initial concentration of leucine used. Larson, Ross \& Tapley (I964) obtained values of up to 10 for serosal:mucosal leucine uptake when the initial concentration was decreased to $0.05 \mathrm{~mm}$.

There was an $18 \%$ decrease in the glucose content of the mucosal fluid after incubation of the sacs for $30 \mathrm{~min}$. This value is similar to that found by Wilson \& Wiseman (1954) who reported a loss of $23 \%$ of the glucose from everted sacs of rat small intestine after incubation for $\mathrm{I} \mathrm{h}$ at $37^{\circ}$. Wilson (I956) showed that the loss of glucose was accompanied by an increase in the lactic acid concentration in the serosal fluid and that up to $75 \%$ of the glucose lost was recovered as lactic acid. Wilson (I956) concluded that this was not an artifact caused by inadequate oxygenation of the tissue but represented true aerobic glycolysis. In the present experiments the amount of lactate found in the serosal fluid was $269 \pm 28 \mu \mathrm{g} / \mathrm{ml}$. This was probably formed from the glucose lost from the mucosal fluid, but since the concentration of glucose present in the serosal fluid was not measured no estimate of the conversion of absorbed glucose to lactate can be made.

A difficulty in the interpretation of these experiments is that the 'unavailable peptides' are unavailable only in the sense that they are relatively slow to digest. The peptides are not absolutely unavailable, as may be seen from Table 3. Thus, the leucine was approximately $26 \%$ available as measured with Strep. zymogenes. This content of available leucine was certainly not present initially as the free amino acid but was liberated by the proteolytic enzymes of Strep. zymogenes. It is possible, therefore, that in the everted sac experiments some of the leucine in the peptides might have been released during the period of incubation to compete with the added leucine for uptake. It is clear however that no significant quantity of leucine was released in this way. The peptide material contributed only approximately $6 \mu \mathrm{g}$ available leucine $/ \mathrm{ml}$ as compared with $130 \mu \mathrm{g}$ leucine $/ \mathrm{ml}$ already present initially in the mucosal fluid. Furthermore, the results for the uptake of leucine as measured microbiologically and by radioactivity measurement showed that there was no dilution of the ${ }^{14} \mathrm{C}$-labelled leucine.

It is interesting to speculate about the mechanism whereby 'unavailable peptide' might obstruct amino acid uptake. Buraczewski et al. (1967) pictured the 'unavailable peptides' as occupying sites involved in amino acid transport, but if we accept that peptide transport systems are independent of the uptake mechanisms for free amino acids (cf. Matthews, 1971; Payne \& Gilvarg, 197I) then this explanation becomes less convincing. The reduction in leucine uptake found in this study could perhaps be explained as an allosteric effect, resulting from attachment of the peptides to binding sites adjacent to the sites for amino acid uptake; or it might be that 'unavailable peptides' are transported into the mucosal cells and there accumulate to the extent that they interfere with the normal cell function.

Another possibility is that the 'unavailable peptides' hinder the transport of amino acids via the ' $\gamma$-glutamyl cycle'. $\gamma$-Glutamyltranspeptidase $(E C 2.3 .2 .1)$ is widely distributed in animal tissues. It is present in the apical portion of the epithelial cells covering the jejunal villi, and Orlowski \& Meister (1970) have suggested that this enzyme is one of several that act together in a non-specific amino acid transport process, to which they refer as the $\gamma$ glutamyl cycle. Current concepts of amino acid transport picture a multi-step process in which the amino acid first interacts with a membrane-bound carrier. This step is followed by translocation of the amino acid or amino acid-carrier complex to the inside of the cell, where dissociation and release of the amino acid occurs (cf. Pardee, I968). $\gamma$-Glutamyltranspeptidase catalyzes the transfer of the $\gamma$-glutamyl moiety of glutathione to a variety of amino acids, and the first step in amino acid transport might be the combination of free amino acid and glutathione under the action of this enzyme, which then shuttles the $\gamma$ glutamyl amino acid across the cell membrane. The enzyme transfers the $\gamma$-glutamyl moiety from $\gamma$-glutamyl peptides other than glutathione, and it might be that 'unavailable peptides' 
containing for example $\epsilon$-( $\gamma$-glutamyl)-lysine are released during the digestion of heatdamaged protein (cf. Bjarnason \& Carpenter, 1970), providing an alternative substrate that resists subsequent hydrolysis by the peptidase and so interrupts the cycle.

Whatever the explanation, our findings support those of Buraczewski et al. (1967). It remains now to isolate representative 'unavailable peptides' and to study their influence on amino acid transport.

\section{REFERENCES}

Barton-Wright, E. C. (1963). Practical Methods for the Microbiological Assay of the Vitamin B complex and Amino Acids. London: United Trade Press Ltd.

Bjarnason, J. \& Carpenter, K. J. (1970). Br. J. Nutr. 24, 313.

Boyne, A. W., Ford, J. E., Hewitt, D. \& Shrimpton, D. H. (1975). Br. J. Nutr. 34, I53.

Buraczewski, S., Buraczewska, L. \& Ford, J. E. (1967). Acta biochim. pol. 14, 21.

Dahlqvist, A. (1964). Analyt. Biochem. 7, I8.

Ford, D. J. (197I). Some aspects of digestive physiology of germ-free and conventional chicks. PhD thesis, University of Reading.

Ford, J. E. (1962). Br. J. Nutr. 16, 409.

Ford, J. E. (1964). Br. J. Nutr. 18, 449.

Ford, J. E. (1965). Br. J. Nutr. 19, 277.

Ford, J. E. \& Salter, D. N. (1966). Br. J. Nutr. 20, 843.

Ford, J. E. \& Shorrock, C. (1971). Br. J. Nutr. 26, 31 I.

Krebs, H. A. \& Hensleit, K. (1932). Hoppe-Seyler's Z. physiol. chem. 210, 33.

Larson, P. R., Ross, J. E. \& Tapley, D. F. (1964). Biochim. biophys. Acta 88, 570.

Matthews, D. M. (1971). J. clin. Path 24, suppl. 29.

Orlowski, M. \& Meister, A. (1970). Proc. natn. Acad. Sci. U.S.A. 67, 1248.

Pardee, A. B. (1968). Science, N.Y. 162, 632.

Payne, J. \& Gilvarg, C. (1971). In Advances in Enzymology, pp. 187, 225 [Alton Meister, editor]. Interscience Publishers.

Shorrock, C. (1976). Br. J. Nutr. 35, 333.

Wilson, T. H. (1956). J. biol. Chem. 222, 751 .

Wilson, T. H. \& Wiseman, G. (1954). J. Physiol., Lond. 123, I16. 